\section{Birlesik Dúnya Arastrrma Cypriot Journal of Educational BD-CENTER \\ Sciences}

Innovasyon ve Yayınalık Merkezi
Volume 15, Issue 5, (2020) 1053-1064

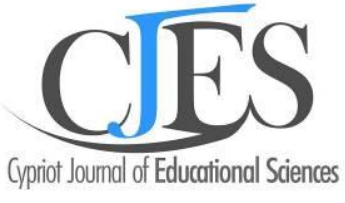

www.cjes.eu

\title{
The effect of music education on the social values of preschool children ${ }^{i}$
}

Erhan Öztürk ${ }^{*}$, Student at the Institute of Educational Sciences, Marmara University,34722 Kadıköy/ Istanbul, Turkey https://orcid.org/0000-0003-4375-1333

Ajda Aylin Can ${ }^{\text {b }}$ Departmant of Music Teacher Education/ Fine Arts, Atatürk Faculty of Education, Marmara University, 34722 Kadıköy/ Istanbul, Turkey https://orcid.org/0000-0001-9332-0385

Suggested Citation:

Öztürk, E., \& Can A, A., (2020). The effect of music education on the social values of preschool children. Cypriot Journal of Educational Science. 15(5), 1053-1064 https://doi.org/10.18844/cjes.v15i5.5150

Received from 06 August, 2020; revised from September 09, 2020; accepted from October 18, 2020.

C2020 Birlesik Dunya Yenilik Arastirma ve Yayincilik Merkezi. All rights reserved.

\begin{abstract}
This study aims to explore the effect of music education on the acquisition of social values by preschool children. In this study, a quasi-experimental pattern model with the pretest-posttest control group is employed. The Preschool Social Values Scale is used for collecting the data. The participants of this study are 26 preschool children (the experimental and control groups contain 13 children each). Whilst the experimental group underwent 30 minutes of music training twice a week for 10 weeks, the control group pursued their preschool education. Music education with the experimental group consists of activities, where students are active and experience music. Songs containing social values were taught to children in the unity of play music and movement. At the end of the study, the scores related to the social values of the experimental group improved as compared to that of the control group. No meaningful difference was detected between the posttest and follow-up test social values' scores.
\end{abstract}

Keywords: Music education, social values, preschool education, value education.

\footnotetext{
*ADDRESS FOR CORRESPONDENCE: Erhan Öztürk, Student at the Institute of Educational Sciences, Marmara University,34722 Kadıköy/ Istanbul, Turkey E-mail address: erhanozturktr@gmail.com / Tel.: +90-216-347-1161
} 
Öztürk, E., \& Can A, A., (2020). The effect of music education on the social values of preschool children. Cypriot Journal of Educational Science. 15(5), 1053-1064 https://doi.org/10.18844/cjes.v15i5.5150

\section{Introduction}

Children spend time apart from their families and socialise with their peers after enrolling in preschools. During the socialisation process, children encounter several social rules and begin to understand the expectations of the people around them to comply with the social rules (Dereli-Iman, 2014). This process determines their thoughts and behaviours in social situations. The attitudes and behaviours exhibited by children in the events that they encounter are shaped according to their acquired social values.

The values are beliefs that affect people's social behaviour. Accordingly, individuals act according to their values in their social actions, attitudes, moral judgements, ideologies, evaluations and justifications, in comparing themselves with others, in attempts to express themselves and influence others (Rokeach, 1973). Schwartz (1994) explained the values as desirable intentional goals that act as leading principles in the life of a person or group. Values are rules that affect the individuals' thinking, decision-making and selection processes. They can prevent behaviours that are not tolerated acting as a control mechanism in the individuals' behaviours (Sapsaglam \& Omeroglu, 2016). Kandir and Alpan (2008) stated that the values acquired by people in their early childhood play a vital role in forming the personality structure, habits, attitudes and value judgements of their adult selves. Therefore, the acquisition of values by children during the preschool period is vital for securing a morally healthy society.

Social values define and shape the societies which adopt them (Naylor \& Diem, 1987). All values of the individual, who is obliged not only to live alone but also to live a social life, constitute social values. The values that regulate the relations of society with the individual and the individual with the society are social values (Gungor, 2008). Behaviours that are accepted as good and evil, found right or wrong, desired or unwanted and liked or disliked in the society are the basic concepts that create social values. Children learn to respect themselves and other people through social value education. Due to this education, they learn to love nature and animals, and this love transforms into a tolerance towards all living beings. They undertake responsibility and fulfil their responsibilities. They act with a sense of benevolence. They learn to work collaboratively and show kindness to their environment. The basis of the acquisition of all these values is laid in education in the preschool period (Atabey \& Omeroglu, 2016).

Today, the rapid growth of technology has increased the access to information and has provided some advantages for the education of children. However, it has negatively impacted the inculcation of values in children. According to Alpoge (2011), an individual's time spent with their family members has decreased due to the social changes caused by the advances in science and technology. This has increased the individual's ability to act individually. Therefore, schools and families must ensure that children acquire social values. Balat and Dagal (2006) stated that value education should be included in the preschool curriculum because it affects the academic success and friendship relations of children. The inclusion of social values such as tolerance, love, honesty, respect, responsibility, cooperation, happiness and peace in the education curriculum positively affects the physical, spiritual, mental and moral development of children (Albu, 2015). It is seen that the children who adopt and internalise the values at an early age feel confident, make their own decisions and solve their problems. Adopting values also contribute to children's happiness (Alpoge, 2011). Due to these factors, the 19th National Education Council decided to include the value education in the preschool programme (MEB, 2014).

Music education is effective in cultivating social harmony, promoting social interactions and inculcating a sense of responsibility in young children (Hallam, 2010). Children who received music education for 3 years in preschool increased their initiation of social interactions and had more positive emotional reactions as compared to those who did not receive music education (Forrai, 1997). It has been observed that the participation of 4-year-old children in collective music activities (such as playing drums, singing, dancing) was effective in the development of their helping and cooperation behaviours (Davies et al., 2013; Kirschner \& Tomasello, 2009). In another study, it is shown that after 
Öztürk, E., \& Can A, A., (2020). The effect of music education on the social values of preschool children. Cypriot Journal of Educational Science. 15(5), 1053-1064 https://doi.org/10.18844/cjes.v15i5.5150

3- to 4-year-old children participated in the preschool music programme, there was an increase in their instrumental sharing and solidarity scores (llari et al., 2019). Participation in collective music activities affects infants similarly. There was an improvement in the communication, social and musical skills of babies who attended active music classes with their families (Gerry et al., 2012). It is seen that collective music making supports the social development of children in early childhood.

In many of the research works on the interrelation between music education and social development of children, the studies focus on the development of social behaviour and social skills in children (Blandford \& Duarte, 2004; Good \& Russo, 2016; Rabinowitch et al., 2012). Few studies are found in the literature on music education and values. These studies were generally conducted with secondary school children (Akarsu, 2015; Egilmez, 2016; Karagoz, 2013). There are a limited number of research works in the literature on value and music education in preschool period (De Vries, 2007; Lee, 2014). Considering the importance of preschool age in shaping children and the music education's effect on the development areas of the children, this study is thought to contribute to this area. Thus, this study aims to examine the effect of music education (including the performance of musical plays, playing rhythm accompaniment and singing songs with the themes of social values) on the acquisition of social values by preschool children.

\subsection{Problem}

The aim of this study is to discover whether music education might have any role in preschool children's attainment of social values. For this purpose, the problem question of the study is does preschool children acquire social values through music education? Based on this problem, the following questions will be tested:

- Is there a statistically meaningful difference between the pretest and posttest scores of the experimental group with respect to the preschool social values?

- Is there a statistically meaningful difference between the posttest and follow-up scores of the experimental group with respect to the preschool social values?

\subsection{Limitations}

The findings of the study are limited to the 2018-2019 academic years in terms of time, social values in terms of subject and preschool children with normal development in terms of sample.

\section{Methodology}

\subsection{Research design}

The study design is quasi-experimental pattern model with the pretest-posttest control group. Two of the previously prepared groups are matched according to certain variables in this model. After the matched groups are randomly selected to the practice groups, the subjects in the two groups are measured on the dependent variable before the application begins. In practice, the experimental process whose effect is examined is given only to the experimental group, and no operation is made to the control group. When the study is completed, the subjects in the groups are remeasured with the same tool or peer forums (Buyukozturk et al., 2015).

\subsection{Participants}

The participants $(N=26)$ of this study are two groups of preschool students from a school in Kartal/Istanbul, Turkey. Participants were selected from the purposeful sampling methods through homogeneous sampling. With homogeneous sampling, it is aimed to select a similar subgroup that is given priority depending on the purpose (Buyukozturk et al., 2012). In determining the low socioeconomic level, the data of the district national education directorate were taken into account. The Kartal District Directorate of National Education was interviewed; the neighbourhoods where socioeconomically underdeveloped families migrated from Anatolia lived were determined, and a primary school with two kindergartens was selected amongst these neighbourhoods. The 
Öztürk, E., \& Can A, A., (2020). The effect of music education on the social values of preschool children. Cypriot Journal of Educational Science. 15(5), 1053-1064 https://doi.org/10.18844/cjes.v15i5.5150

experimental and control groups were selected from the same school to have the similar cultural characteristics. It was noted that the preschool children had not been trained by a music educator before. This research was carried out in the academic year 2018-2019. The experimental group consisted of 13 children: four girls and nine boys ( $N_{\mathrm{e}}=13$; age range: $60-66$ months). The control group consisted of 13 children: five girls and eight boys $\left(N_{\mathrm{c}}=13\right.$; age range: $60-66$ months) Considering the education of the parents of the participants, whilst $8 \%$ of the participants' mothers and $24 \%$ of the participants' fathers are university graduates, $58 \%$ of the participants' mothers and $4 \%$ of the participants' fathers are unemployed.

\subsection{Data collection tools}

The Preschool Social Values Acquisition Scale (Atabey \& Omeroglu, 2016) is used for obtaining the data of this research. In addition, the participants' families were asked to complete the personal information form that contained the demographic information of the children.

The Preschool Social Values Acquisition Scale (Atabey \& Omeroğlu, 2016) has five subdimensions: love-tolerance, respect, responsibility, cooperation-helping and courtesy. The five subdimensions consist of 19 items. The love-tolerance sub-dimension consists of four items, the respect sub-dimension consists of four items, the responsibility sub-dimension consists of five items, the cooperation-helping sub-dimension consists of three items and the courtesy sub-dimension consists of three items. The KR-20 reliability coefficients for the love-tolerance sub-dimension were 0.82 . It was 0.85 for the respect sub-dimension, 0.78 for the responsibility sub-dimension, 0.75 for the cooperation-helping sub-dimension and 0.83 for the courtesy sub-dimension. The KR-20 reliability coefficient for the total scale was 0.88 . These outcomes prove that the scale has a high level of reliability with regard to all its sub-dimensions.

In the process of collecting the data with the utilisation of the Preschool Social Values Scale (Turkish version of the scale was used), the children were asked to enter a room one by one. One of the researchers asked the children to respond to the scale items by sitting on a chair and table suitable to their height. The scale items were presented in a pictorial form. They were shown a picture describing a situation and were provided three smaller pictures that represented the possible solution for that situation. For example, for the situation representing the item 'Respect the rights of self and others' that constitutes the respect sub-dimension, the teacher instructs the children to form a queue to wash their hands. Mert wants to wash his hands by jumping the queue before his friends. What should Ezgi do in this situation? The three smaller pictures provided to the children are as follows:

- Ezgi should talk to Mert and ask him to follow the queue order for washing hands.

- Mert should wash his hand.

- Ezgi and Mert should wash their hands together.

The student chooses the appropriate picture for the situation.

\subsection{Procedure}

The experiment conducted for this research lasted for a total of 12 weeks. The first and last weeks of the experiment were reserved for conducting the pretest (T1) and posttest (T2). After the study groups and pretests (T1) were determined, the music activities based on social values were conducted for the experimental group, and no activities were conducted for the control group. When the experimental group completed the 10-week music education, both the groups were subjected to a posttest (T2), and 3 weeks after the posttest (T2), the experimental group was subjected to a followup test (T3). The results of these tests were reported after statistical analysis.

The experimental group training was carried out in the form of 30-minute lessons conducted for 2 days a week (Monday and Wednesday) for 10 weeks. A children's song was composed for each value mentioned in the Preschool Social Values Scale. The lessons consisted of music instruments (guitars, maracas, shakers and rhythm sticks), rhythm activities, movement games and stories and 
Öztürk, E., \& Can A, A., (2020). The effect of music education on the social values of preschool children. Cypriot Journal of Educational Science. 15(5), 1053-1064 https://doi.org/10.18844/cjes.v15i5.5150

pictures about the songs. These music activities were utilised to promote active learning in children. The co-author of this article implemented these activities in the role of a teacher. He ensured that the children were actively participating in the lessons and that the elements of movement-play-dancerhythm formed the core of the lessons. The control group was not subjected to any music education.

We applied to the Provincial Research Commission for obtaining the research permit. The research proposal and scale were found to be appropriate for the intellectual and psychological level of the students, and the necessary permissions were obtained for conducting this research. For the implementation of the research, the informed consent of the parents and the school administration was obtained. The participants took part in the research on a voluntary basis. The confidentiality and anonymity of the participants were ensured whilst conducting the experiment. An example of a music activity can be seen at appendices.

\subsection{Data analysis}

The data of the pretest (T1), posttest (T2) and follow up (T3) were collated and analysed with statistical methods. The Kolmogorov-Smirnov test was carried out to decide whether the groups were normally distributed or not. The test determined that the groups were not normally distributed (The $p$-values of the experimental group are between 0.015 and 0.040 . The $p$-values of the control group are between 0.00 and 0.017 ). Hence, the Mann-Whitney U-test was utilised in testing the difference between the two independent groups. The difference between the two dependent groups was tested by using the Wilcoxon signed-rank test.

\section{Results}

This study investigates the effect of music education on the social values of preschool children. The findings regarding the first question of the research are as follows:

Table 1. Social values' pretest (T1) Mann-Whitney U-scores of the experimental and control groups

\begin{tabular}{llllllll}
\hline $\begin{array}{l}\text { Sub- } \\
\text { dimensions }\end{array}$ & Group & $N$ & $\begin{array}{l}\text { Mean } \\
\text { rank }\end{array}$ & Rank sum & $U$ & $Z$ & $p$ \\
\hline $\begin{array}{l}\text { Love- } \\
\text { tolerance }\end{array}$ & Experimental & 13 & 14.35 & 186.50 & 73.50 & -0.601 & 0.548 \\
& Control & 13 & 12.65 & 164.50 & & & \\
\hline Respect & Experimental & 13 & 12.96 & 168.50 & 77.50 & -0.377 & 0.706 \\
& Control & 13 & 14.04 & 182.50 & & & \\
\hline Responsibility & Experimental & 13 & 14.15 & 184.00 & 76.00 & -0.455 & 0.649 \\
& Control & 13 & 12.85 & 167.00 & & & \\
\hline Cooperation- & Experimental & 13 & 13.35 & 173.50 & 82.50 & -0.110 & 0.912 \\
helping & Control & 13 & 13.65 & 177.50 & & & \\
\hline Courtesy & Experimental & 13 & 12.62 & 164.00 & 73.00 & -0.659 & 0.510 \\
& Control & 13 & 14.38 & 187.00 & & & \\
\hline Overall & Experimental & 13 & 13.35 & 173.50 & 82.50 & -0.104 & 0.918 \\
Total & Control & 13 & 13.65 & 177.50 & & & \\
Scale & Total & 26 & & & & & \\
\hline
\end{tabular}


Öztürk, E., \& Can A, A., (2020). The effect of music education on the social values of preschool children. Cypriot Journal of Educational Science.

$p>0.05$.

As shown in Table 1, no statistically meaningful difference is observed between overall total scale scores $(U=82.50, p=0.918>0.05)$ of both the groups. No statistically meaningful difference is observed between the sub-dimensions of the experimental and control groups $(p>0.05)$.

Table 2. Social values' posttest (T2) Mann-Whitney U-scores of the experimental and control groups

\begin{tabular}{|c|c|c|c|c|c|c|c|}
\hline $\begin{array}{l}\text { Sub- } \\
\text { dimensions }\end{array}$ & Group & $N$ & Mean rank & Rank sum & $U$ & $Z$ & $p$ \\
\hline \multirow[t]{3}{*}{ Love-tolerance } & Experimental & 13 & 18.46 & 240.00 & 20.0 & -3.526 & 0.000 \\
\hline & & & & & 0 & & \\
\hline & Control & 13 & 8.54 & 111.00 & & & \\
\hline \multirow[t]{3}{*}{ Respect } & Experimental & 13 & 19.23 & 250.00 & 10.0 & -4.003 & 0.000 \\
\hline & & & & & 0 & & \\
\hline & Control & 13 & 7.77 & 101.00 & & & \\
\hline \multirow[t]{2}{*}{ Responsibility } & Experimental & 13 & 19.88 & 258.50 & 1.50 & -4.434 & 0.000 \\
\hline & Control & 13 & 7.12 & 92.50 & & & \\
\hline \multirow{2}{*}{$\begin{array}{l}\text { Cooperation- } \\
\text { helping }\end{array}$} & Experimental & 13 & 17.88 & 232.50 & 27.5 & -3.100 & 0.002 \\
\hline & Control & 13 & 9.12 & 118.50 & & & \\
\hline \multirow[t]{3}{*}{ Courtesy } & Experimental & 13 & 18.77 & 244.00 & 16.0 & -3.789 & 0.000 \\
\hline & & & & & 0 & & \\
\hline & Control & 13 & 8.23 & 107.00 & & & \\
\hline \multirow{4}{*}{$\begin{array}{l}\text { Overall } \\
\text { scale }\end{array}$} & Experimental & 13 & 20.00 & 260.00 & 91.0 & -4.364 & 0.000 \\
\hline & & & & & 0 & & \\
\hline & Control & 13 & 7.00 & 91.00 & & & \\
\hline & Total & 26 & & & & & \\
\hline
\end{tabular}

$p<0.05$

As shown in Table 2, a significant difference in favour of the experimental group is observed between the posttest overall total scale social values scores of the experimental and control groups $(U=91.00$, $p=0.000<0.05)$. A meaningful difference in favour of the experimental group is observed in all of the sub-dimensions $(p<0.05)$.

The findings related to the second question of the research are as follows: 
Öztürk, E., \& Can A, A., (2020). The effect of music education on the social values of preschool children. Cypriot Journal of Educational Science. 15(5), 1053-1064 https://doi.org/10.18844/cjes.v15i5.5150

Table 3. Wilcoxon signed-rank test results of the experimental group's posttest (T2) and follow-up (T3) scores

\begin{tabular}{|c|c|c|c|c|c|c|}
\hline Sub-dimensions & Pretest-posttest & $N$ & $\begin{array}{l}\text { Mean } \\
\text { rank }\end{array}$ & Rank sum & $Z$ & $p$ \\
\hline \multirow[t]{3}{*}{ Love-tolerance } & Negative rank & 1 & 1.00 & 1.00 & -1.000 & 0.317 \\
\hline & Positive rank & 0 & 0.00 & 0.00 & & \\
\hline & Equal & 13 & & & & \\
\hline \multirow[t]{3}{*}{ Respect } & Negative rank & 0 & 0.00 & 0.00 & 0.000 & 1.000 \\
\hline & Positive rank & 0 & 0.00 & 0.00 & & \\
\hline & Equal & 13 & & & & \\
\hline \multirow[t]{3}{*}{ Responsibility } & Negative rank & 0 & 0.00 & 0.00 & 0.000 & 1.000 \\
\hline & Positive rank & 0 & 0.00 & 0.00 & & \\
\hline & Equal & 13 & & & & \\
\hline \multirow{3}{*}{$\begin{array}{l}\text { Cooperation- } \\
\text { helping }\end{array}$} & Negative rank & 0 & 0.00 & 0.00 & 0.000 & 1.000 \\
\hline & Positive rank & 0 & 0.00 & 0.00 & & \\
\hline & Equal & 13 & & & & \\
\hline \multirow[t]{3}{*}{ Courtesy } & Negative rank & 0 & 0.00 & 0.00 & 0.000 & 1.000 \\
\hline & Positive rank & 0 & 0.00 & 0.00 & & \\
\hline & Equal & 13 & & & & \\
\hline \multirow[t]{3}{*}{ Overall total scale } & Negative rank & 0 & 0.00 & 0.00 & 0.000 & 1.000 \\
\hline & Positive rank & 0 & 0.00 & 0.00 & & \\
\hline & Equal & 13 & & & & \\
\hline
\end{tabular}

$p>0.05$.

As shown in Table 3, no meaningful difference was seen between the experimental group's posttest and follow-up social values' overall total scale test scores $(Z=0.000, p=1.000>0.05)$. No meaningful difference was seen between the experimental group's posttest and follow-up social value subdimensions' scores $(p>0.05)$.

\section{Discussion and conclusion and recommendations}

\subsection{Discussion and conclusion}

This research investigates the effect of music education on the social values of preschool children. No meaningful difference was observed between the pretest scores of the children in the experimental and control groups. Kaptan (1998) stated that the pretest scores of the children in both these groups should be as close as possible at the commencement of a study. In this research, both the experimental and control groups had similar social values' pretest scores. It is thought that the absence of a statistical difference in the social values' pretest scores of both the groups is because the study was conducted in a school that contained children with similar sociocultural characteristics.

At the end of this research, a meaningful difference was observed between the experimental and control group students' posttest (T2) scores. According to this result, the experimental group's 
posttest (T2) scores of love-tolerance, respect, responsibility, cooperation-helping and courtesy and the scores of the overall total scale were more favourable than that of the control group. It is thought that this result may be due to the positive effect of music education applied to the experimental group. In this research, music education was applied in the form of activities, in which the students use their bodies as a musical instrument, repeat the rhythms that they hear from the teacher, play games and sing songs based on social values. These activities continued for 10 weeks and were conducted in $30-$ minute periods twice a week, and they were realised with the active participation of students. It is concluded that this music education had a positive impact on the social values (respect, love-tolerance, responsibility, cooperation and cooperation and kindness) of the preschool students. As the students come from families with low socioeconomic level and have not received special music education before, it is thought that these new and different applications may have a positive effect on their social values.

In an experimental study conducted by Akarsu (2015) with 7th grades, tolerance sensitivity, sharing and responsibility posttest scores of the experimental group students who received music education with value-themed songs were found higher than the posttest scores of the control group. A similar result is found in the research of Karagoz (2013). Egilmez (2016) investigated the effect of songs including social messages on the perception of social values of children of different ethnic backgrounds. At the end of the research, the positive perception of children towards social values increased due to their experiencing songs containing social messages. The result of the current study matches the results of the above studies.

In an experimental study conducted by Kirschner and Tomasello (2009), an improvement was observed in the level of cooperation and helping of children aged 4 years (who participated in music activities such as hand drumming, singing and dancing) compared to the control group who did not engage in music activities. Davies et al. (2013) also found that 4-year-old children who played percussion instruments and sang songs behave more helpfully and co-operate better. Ilari et al. (2019) examined the effect of music participation - at a preschool music programme and at home-to the instrumental sharing and helping scores of 3-4 years of children. The results showed that the musical participation may affect the prosocial behaviours (sharing and helping) of the children. The result obtained in the current research is in line with the similar research results above.

De Vries (2007) suggested in his study that participating children in music education may assist the teaching of value education, especially during the early childhood period. Lee (2014) reported that music activities in preschools have a positive impact on the inculcation of the values of courage, cooperation, respect, responsibility and honesty in children. In addition, Lee recommended that music education should be included in the preschool curriculum to assist the character development of children. Muldma and Kiilu (2012) stated that children develop the values of respect, tolerance, cooperation, communication and kindness by singing and making music together. Kurtaslan et al. (2015) also stated that making music collectively contributes to the development of values in students. In a study, they found that university music students acquire responsibility, benevolence, patience, tolerance, solidarity, empathy, diligence, self-efficacy and discipline via orchestra/chamber music participation. In Dolgun's study (2017), university students were divided into three different groups. They experienced the learning of values through creating musical plays. At the end of the research, it was found that teaching the values of tolerance, love and respect to children through musical games contributes to an effective inculcation of values. It can be said that the results of both experimental and case studies in the literature support the findings of the current study.

Another result of this research is that no meaningful difference was discovered between the posttest (T2) and follow-up (T3) scores of the children in the experimental group. This result indicates that the effect of music education implemented on the experimental group on the social values of children continues. In the related literature, no conclusion has been reached on the permanent effect of music education on social values. The current result may be due to the engagement of the students with the activities based on the social value-themed songs. Muldma and Kiilu (2012), Lee (2014), 
Öztürk, E., \& Can A, A., (2020). The effect of music education on the social values of preschool children. Cypriot Journal of Educational Science. 15(5), 1053-1064 https://doi.org/10.18844/cjes.v15i5.5150

Egilmez (2016) and Donmez et al. (2019) suggested that song lyrics can be effective in teaching values to children. However, much research is needed to verify the different interpretations regarding this factor.

\subsection{Recommendations}

This research indicates that music education can have a positive and lasting effect on the social values of preschool children. In light of this research, the following changes are suggested in the preschool curriculum: songs can be used in providing value education to children, and social value-themed songs can be composed and published for the benefit of the children.

The examination of the effect of music on the acquisition of social values by preschool children can also be extended to different age groups. This research was conducted in a region, wherein the majority of the population had a low socioeconomic status. Future research works can be conducted in different regions possessing different socioeconomic characteristics. In this study, the situation of the control group at the end of the study was not examined. In similar studies, the reasons for the probable changes in the control group can also be investigated.

In this research, the songs containing the message of social values were taught with the active participation of the students. It can be investigated whether or not similar results are obtained in music lessons that are conducted without teaching songs to children.

This research covers only one academic year and consists of 20 lessons for 10 weeks. To investigate the long-term impacts of music education on the social values of children, the research period can be extended to longer periods (e.g., 1 year).

The effect of music education on the permanence of social values in individuals should be investigated in further studies.

\section{Appendices:}

An example of a music activity:

Topic: Cooperation-helping

Outcome: Children collaborate and help each other.

Tools and Materials: The story of the turtle and rabbit in the form of a song (accompanied with music from a guitar, egg shakers and rhythm sticks).

(1) Warm-up activity is conducted for the children.

(2) The children were asked to pick up the toys from the floor together (with music). Toys were scattered on the floor and the children were asked to collect the toys from the floor until the end of the music.

Question: Would it be easy if one person picked up the toys? After discussing the answer to this question, the lyrics of a song were taught to the children. The words were spoken by children with the accompaniment of body percussion.

The following words were sung by the children by tapping their knee-hand-foot in a rhythm:

Force comes out of the union,

One hand has no power, two hands have a voice.

The story of an old turtle falling into a pit was narrated to the children. This story described how the rabbit who was passing by the road helped the turtle to get out of the pit.

The story of the old turtle

An old turtle woke up from his sleep one day and decided to go to a forest that had its favourite trees. This forest was nearby, but it took some time for the turtle to reach the forest because it was walking very slowly. The turtle was very excited to see the trees it loved so much. The turtle travelled along a 
Öztürk, E., \& Can A, A., (2020). The effect of music education on the social values of preschool children. Cypriot Journal of Educational Science. 15(5), 1053-1064 https://doi.org/10.18844/cjes.v15i5.5150

familiar road. However, something happened on the road. The turtle did not notice (the question of 'what happened?' is posed to the children at this moment to attract their attention) its path. The path that the old turtle walked on suddenly collapsed and the turtle fell into a deep pit. The pit was so deep that no matter how hard the turtle tried, it could not get out of the pit. (Question: how do you think the turtle got out of the pit? After discussing the answer with the children, the story narration is continued). Soon after, a rabbit friend saw the turtle stuck in the pit. It jumped in the pit and carried the turtle up to the ground with his big legs.

Play: The children formed a circle. A child stood in the middle of the circle (representing the turtle trapped in the pit), and the other children went round the circle holding hands and singing the song. All the children lifted the turtle to the ground whilst singing it has pulled the turtle up with its long arms'. After this process, another child played the character of the turtle. The children sang the following song:

An old turtle has fallen into the pit

It tried hard but could not go up

A rabbit passing by noticed the turtle

It pulled up the turtle to the ground with his long arms

One hand has no power, both hands have a voice

Force arises from unity,

If we help each other, we become stronger

We overcome the difficulties immediately

After the song is sung with the music-movement-play items, the lesson learned is transferred to the activity with the instruments. The teacher played the guitar, and the students sang along whilst playing an egg shaker and rhythm sticks.

\section{References}

Albu, G. (2015). Pre-primary education teachers and their values in the context of current education: Case study. Procedia-Social and Behavioral Sciences, 180(2015), 477-483. https://doi.org/10.1016/j.sbspro.2015.02.147

Akarsu, S. (2015). Ilkokul ve ortaokul muzik ders kitaplarinda yer alan sarkilarin deger bakımindan incelenmesi ve degerler egitimine iliskin ogrenci algilari [Examination of the songs in the music textbooks of primary school (1-4) and middle school (5-8) in terms of values and students' perceptions about values education] [Yayimlanmamis doktora tezi, Van Yuzuncu Yil Universitesi Egitim Bilimleri Enstitusu, Van].

Alpoge, G. (2011). Okul oncesinde deger egitimi [Value education in preschool]. Bilgi Yayinevi.

Atabey, D., \& Omeroglu, E. (2016). Okul oncesi sosyal degerler kazanimi olceginin gelistirilmesi [A study into the development of scale for preschool social values acquisition]. Balikesir Universitesi Sosyal Bilimler Enstitusu Dergisi, 19(35), 101-135. https://hdl.handle.net/11491/3618

Balat, G. U., \& Dagal, A. B. (2006). Okul oncesi donemde degerler egitimi etkinlikleri [Values education activities in preschool period]. Kok Yayincilik.

Blandford, S., \& Duarte, S. (2014). Inclusion in the community: A study of community music centers in England and Portugal, focusing on the development of musical and social skills within each center. Westmister Studies in Education, 27(1), 7-25. https://doi.org/10.1080/0140672042000224934

Buyukozturk, S., Cakmak, E., Akgun O., Karadeniz, S., \& Demirel, F. (2015). Bilimsel Arastirma Yontemleri [Scientific research methods]. Pegem Akademi. 
Öztürk, E., \& Can A, A., (2020). The effect of music education on the social values of preschool children. Cypriot Journal of Educational Science. 15(5), 1053-1064 https://doi.org/10.18844/cjes.v15i5.5150

Davies, R., Ohl, M., \& Manyande, A. (2013). Making music may improve young children's behavior. Science Daily. https://www.sciencedaily.com/releases/2013/09/130905202851.htm on 02.07.2020.

De Vries, P. (2007). Values education: An opportunity to enhance the profile of music education in early childhood settings. Musicworks, 12(1), 14-18.

Dereli-Iman, E. (2014). The effect of values education program on 5.5-6 years old chidren social development: Social skills- psycho- social development and social problem solving skills, Educational Sciences: Theory \& Practice, 14(1), 262-268. https://doi.org/10.12738/estp.2014.1.1679

Dolgun, B. O. (2017). Gaining values education through musical plays. IOSR Journal of Research and Method in Education, 7(1) IV, 42-47. https://doi.org/10.9790/7388-0701044247

Donmez, E. C., Kurtaslan, Z., Apaydin A. I., \& Okay, H. H. (2017). Muzik ve deger kazanimi iliskisi (Music and appreciation relationship). In H. H. Bircan \& B. Dilmac (Eds.), Degerler Bilancosu (Beyaz Kitap) [Balance of values (White Book)] (pp. 319-328). Cizgi Kitabevi.

Egilmez, H. O. (2016). Effects of songs containing social messages on the perceptions of Romani students about social values. The Antropolojist, 24(2), 2016. https://doi.org/10.1080/09720073.2016.11892053

Forrai, K. (1997). The influence of music on the development of young children: Music research with children between 6 and 40 months. Early Childhood Connections, 3(1), 14-18. https://eric.ed.gov/?id=EJ578101

Gerry, D., Unrau, A., \& Trainor, L. J. (2012). Active music classes in infancy enhance musical, communitive and social development. Developmental Science, 15(3), 398-407. https://doi.org/10.1111/j.14677687.2012.01142.x

Good, A. \& Russo, F. A (2016). Singing promotes cooperation in a diverse group of children. Social Psychology, 47(6), 340-344. https://doi.org/10.1027/1864-9335/a000282

Gungor, E. (2008). Ahlak psikolojisi ve sosyal ahlak [Moral psychology and social morality]. Otuken Yayinlari.

Hallam, S. (2010). The power of music: Its impact on the intellectual, social and personal development of children and young people. International Journal of Music Education, 28(3), 269-289. https://doi.org/10.1177/0255761410370658

Ilari, B., Helfter, S., \& Huyhn, T. (2019). Associations between musical participation and young children's prosocial behaviours. Journal of Research in Music Education, 67(4), 399-412. https://doi.org/10.1177/0022429419878169

Kandir, A., \& Alpan, Y. (2008). Okul oncesi donemde sosyal-duygusal gelisime anne-baba davranislarinin etkisi [The effect of parental behaviour on the social- emotional development in preschool]. Sosyal Politika Calismalari Dergisi, 14(14), 33-38. https://dergipark.org.tr/en/pub/spcd/issue/21109/227348

Kaptan, S. (1998). Bilimsel arastirma ve istatistik teknikleri [Scientific research and statistical techniques]. Tekisik.

Karagoz, B. (2013). Ilkogretim ogrencilerine degerlerin sarkilar yoluyla kazandirilmasi [Teaching values to elementary students using school songs] [Yayinlanmamis Doktora Tezi, Inonu Universitesi Egitim Bilimleri Enstitusu, Malatya].

Kirschner, S., \& Tomasello, M. (2009). Social context facilitates synchronization in preschool children. Journal of Experimental Child Psychology, 102, 299-314. https://doi.org/10.1016/j.jecp.2008.07.005

Kurtaslan, Z., Okay, H. H., Donmez, E.C., \& Kucukdogan, I. (2015). Orchestra course outcomes in terms of values education. International Scholarly and Scientific Research\& Innovation, 9(7), 2647-2650. https://panel.waset.org/publication/Orchestra-Course-Outcomes-in-Terms-of-ValuesEducation/10006018

Lee, A. (2014). Implementing character education program through music and integrated activities in early childhood settings in Taiwan. International Journal of Music Education, 34(3), 340-351. https://doi.org/10.1177/0255761414563195

MEB (2014). 19. Milli Egitim surasi kararlari [19. National Education Council decisions]. http://ttkb.meb.gov.tr/meb iys dosyalar/2019 12/10095332_19 sura.pdf

Muldma, M., \& Kiilu, K. (2012). Teachers view's on the development of values in music education in Estonia. Procedia-Social and Behavioral Sciences, 45(2012), 342-350. https://doi.org/10.1016/j.sbspro.2012.06.570

Naylor, D. T., \& Diem, R. A. (1987). Elementary and middle school social studies. Random House.

Rabinowitch, T. C., Cross, I., \& Burnard, B. (2012). Long-term musical group interaction has a positive influence on empathy in children. Psychology of Music, 41(4), 484-498. https://doi.org/10.1177/0305735612440609

Rokeach, M. (1973). The nature of human values. Free Press. 
Öztürk, E., \& Can A, A., (2020). The effect of music education on the social values of preschool children. Cypriot Journal of Educational Science. 15(5), 1053-1064 https://doi.org/10.18844/cjes.v15i5.5150

Sapsaglam, O. \& Omeroglu, E. (2016). Examining the effect of social values education program being applied to nursery school students upon acquiring social skills, Educational Research and Reviews, 11(13), 12621271. https://doi.org/10.5897/ERR2016.2804

Schwartz, S. H. (1994). Are there universal aspects in the structure and contents of human values? Journal of Social Isues. 50(4), 19-45.

https://doi.org/10.1111/j.1540-4560.1994.tb01196.x

${ }^{i}$ This study was prepared from the doctoral thesis of Erhan Öztürk completed under the counseling of Doc. Dr. A. Aylin Can at Marmara University. 